\title{
PEMBERDAYAAN DAN PERLINDUNGAN HUKUM BAGI KONSUMEN KETIKA TERJADI SENGKETA DENGAN BUMN ATAU PERUSAHAAN DAERAH*
}

\author{
Oleh : \\ Dewa Ayu Agung Chintya Devi Antari** \\ I Wayan Parsa*** \\ Program Kekhusuan Hukum Bisnis \\ Fakultas Hukum Universitas Udayana
}

\begin{abstract}
ABSTRAK
Dalam kegiatan suatu bisnis dimana terdapat suatu hubungan yang saling membutuhkan antara produsen dengan konsumen. Dalam penelitian ini untuk mengidentifikasikan konsumen dalam menyelesaikan sengketa dengan pelaku usaha serta mendeskripsikan upaya-upaya yang dapat ditempuh oleh konsumen dalam rangka penyelesaiian sengketa dengan pelaku usaha. Penelitian ini merupakan penelitian empiris dengan metode kualitatif yang bersifat deskriptif. Penelitian ini menggunakan data primer yang diperoleh dari hasil wawancara dengan informan, maupun data sekunder yang diperoleh dari peraturan perundangundangan, literatur, dokumen-dokumen. Pengumpulan data dilakukan dengan penelitian lapangan dan kepustakaan. Selanjutnya data akan dianalisi secara kualitatif dengan model interaktif. Hasil penelitian menunjukan bahwa terdapat beberapa Masalah yang timbul yaitu apakah faktor dan Bagaimanakah upaya yang dapat menyebabkan konsumen tidak mampu ketika berhadapan dengan pelaku usaha.ketika konsumen berhadapan dengan pelaku usaha BUMN dan Perusahaan Daerah dimana posisi BUMN lebih kuat dibandingkan konsumen. BUMN dan Perusahaan Daerah selalu berkelit untuk memberikan ganti rugi kepada konsumen apabila terjadi kerugian yang menimpa konsumen, Pelaku usaha hanya diwakilkan oleh stafnya sehingga tidak berani memutuskan secara langsung dan Pelaku usaha selalu mengulur waktunya dan pelaku usaha mengatakan bahwa ia akan membentuk tim pengkaji ganti rugi. Pelaku usaha hanya sanggup
\end{abstract}


memperbaiki,menyambung, atau menghidupkan lagi tanpa mau mengganti sesuai dengan perjanjian yang telah di katakan kepada konsumen. Ketika berhadapan dengan pelaku swasta yaitu Pelaku usaha hanya mau mengganti kerugian sekecil mungkin dan Pelaku usaha beralih bahwa aturan yang telah dibuatnya maka itulah yang harus dipatuhi.sehingga proses pelaksanaan penyelesaiian sengketa antara konsumen dengan pelaku usaha melalui tahapantahapan yang telah di tentukan.

\title{
Kata Kunci: Pemerdayaan, perlindungan konsumen, kurang mampu
}

\begin{abstract}
ABSTRAC
In the activities of a business where there is a relationship that requires each other between producers and consumers. In this study to identify consumers in resolving disputes with business people and describing efforts that can be taken by consumers in order to resolve disputes with business actors. This study is an empirical study with qualitative methods that are descriptive. This study uses primary data obtained from the results of interviews with informants, as well as secondary data obtained from legislation, literature, documents. Data collection is done by field research and literature. Furthermore, the data will be analyzed qualitatively with an interactive model. The results of the study show that there are several problems that arise, namely what are the factors and how the efforts can cause consumers to be incapable when dealing with business actors. When consumers are faced with business actors of BUMN and Regional Companies where the position of BUMN is stronger than consumers. BUMNs and Regional Companies always dodge to provide compensation to consumers in the event of a loss that befalls consumers. Business actors are only represented by their staff so they do not dare to decide directly and business actors always buy time and business people say that they will form a compensation assessment team. Business actors are only able to repair, connect, or revive without wanting to replace according to the agreement that has been said to consumers. When dealing with private actors, the business actor is only willing to compensate for the smallest possible loss and the business actor switches to the rules he has made, that is what must be obeyed so
\end{abstract}


that the process of resolving disputes between consumers and business actors goes through the stages that have been determined.

\section{Keywords: empowerment, consumer protection, underprivileged}

\section{PENDAhUluan}

\subsection{Latar Belakang}

Dalam era sekarang ini, semua orang dapat dikatagorikan sebagai masyarakat modern, yakni masyarakat konsumen, Sebab semua orang dalam satu atau lain bentuk tanpa kecuali adalah Konsumen dari salah satu barang yang diperoleh melalui suatu kegiatan bisnis. ${ }^{1}$

Dalam kegiatan suatu bisnis dimana terdapat suatu hubungan yang saling membutuhkan antara produsen dengan konsumen. Hubungan tersebut merupakan hubungan yang terus-menerus dan berkesinambung. Hubungan tersebut terjadi karena keduanya saling menghendaki dan mempunyai tingkat ketergantungan yang tinggi.

Kepentingan produsen adalah memperoleh sebuah laba dari suatu transaksi dengan konsumen, sedangkan kepentingan konsumen adalah memperoleh suatu kepuasan melalui kepenuhan kebutuhannya terhadap suatu produk tertentu. ${ }^{2}$ Namun dengan demikian tidak menutup suatu kemungkinan munculnya dampak negatif yang dirasakan

\footnotetext{
${ }^{1}$ A. Sonny Keraf. 1998. Etika Bisnis Tuntutan dan relevansinya. Yogyakarta : Kanisius.

${ }^{2}$ Bilson Simamora. 2001. remarketing for Business recovery. Jakarta : PT Gramedia Pustaka Utama
} 
oleh konsumen maka akibatnya akan muncul sengketa antara konsumen dengan pelaku usaha.

Lembaga Perlindungan Konsumen Swadaya Masyarakat yang dapat di kategorikan ke dalam beberapa bidang atau golongan komoditi, misal: Peralatan rumah tangga, Makanan dan Minuman, Iklan/Promosi/Undian, Perumahan, Produk Elektronik, Kendaraan dan suku cadang, Air Minum ( Perusahaan Daerah Air Minum/PDAM), Jasa Transportasi dan Jasa lainnya.

Dari beberapa golongan komoditi diatas maka dalam beberapa kasus diperlukan penyelesaiian yang serius terutama terhadap listrik telepon dan air minum. Dalam penelitian ini akan difokuskan pada dua golongan pengaduan yang setiap hari selalu berhubungan langsung dengan masyarakat konsumen, yakni pengaduan listrik (PLN) dan air minum (PDAM). Penelitian ini mencatat bahwa kedua kasus pengaduan tersebut merupakan pengaduan yang bisa dibilang tidak sedikit diadukan oleh masyarakat konsumen untuk di selesaikan kepada pelaku usaha. Penelitian terdahulu mencatat, bahwa dua kasus pengaduan tersebut merupakan pengaduan yang paling banyak diadukan oleh konsumen untuk diselesaikan kepada pelaku usaha. ${ }^{3}$ Secara umum penyelesaian kasus ini melibatkan dua pihak yakni konsumen dan pelaku usaha.

${ }^{3}$ Suraji, Pranoto, "PEMBERDAYAAN DAN PERLINDUNGAN HUKUM BAGI KONSUMEN DALAM RANGKA MELINDUNGI KEPENTINGAN KONSUMEN KURANG MAMPU' Jurnal Ilmiah, Fakultas Hukum Universitas Sebelas Maret Surakarta. 
Bentuk sengketa yang memerlukam penyelesaian antara konsumen dengan pelaku usaha, misalnya dalam pengaduan kasus matinya saluran listrik/golongan jumlah angka meter terbayar tidak sama dengan pemakian dan kasus pengaduan air minum dimana pembayaran angka meter yang tidak sama dengan rill pemakaian, sering matinya saluran air minum. Terjadinya sengketa perlu dihindari untuk menjaga reputasi dan relasi yang baik. Namun demikian suatu sengketa kadang-kadang tidak dapat dihindari karena adanya kesalahpahaman, Pelanggaran perundang-undangan, ingkar janji, kepentingan yang berlawanan, dan/atau kerugian pada salah satu pihak. Dalam beberapa kasus terlihat dampak betapa lemahnya kedudukan konsumen dibandingkan dengan pelaku usaha.

Suatu Yayasan Lembaga Konsumen Indonesia (YLKI) dan Lembaga Pembinaan dan Perlindungan Konsumen (LP2K), Sebagai bagian dari Lembaga Perlindungan Konsumen Swadaya Masyarakat (LPKSM) mempunyai kepedulian yang sangat tinggi dalam menyelesaikan sengketa dokumen dan diharapkan banyak memberikan suatu harapan terhadap upaya untuk mewujudkan pemerdayaan konsumen yang menjadi impian UUPK. ${ }^{4}$

Temuan awal di LP2K ternyata banyak konsumen yang menggunakan jasa lembaga ini untuk menyelesaikan sengketa dengan pelaku usaha. Dimana konsumen tidak

4 Ahmadi Miru. 2011. prinsip-prinsip perlindungan Hukum Bagi Konsumen di Indonesia.Jakarta : PT Radja Grafindo Persada. 
melakukannya lewat jalur pengadilan, melainkan melalui jalur di luar pengadilan.

Faktor utama yang menjadi kelemahan utama konsumen adalah tingkat kesadaran konsumen akan haknuya masih begitu rendah serta masih kurangnya memadai peraturan perundangundang untuk menyetarakan posisi tawar konsumen dengan pelaku udaha dan menjamin hak-hak konsumen. ${ }^{5}$ Hal ini terutama disebabkan oleh kurangnya kesadaran dari pihak konsumen itu sendiri dan rendahnya pendidikan konsumen yang ada. ${ }^{6}$

Posisi tawar yang begitu lemah dalam hal kemampuan ekonomi dan upaya hukum konsumen dalam mempertahankan hak-haknya, mengakibatkan konsumen menjadi objek aktivitas bisnis untuk meraup keuntungan yang sebesar-besarnya oleh pelaku usaha melalui iklan, promosi, cara penjualan, serta penerapan perjanjian standar yang merugikan konsumen. ${ }^{7}$

Berdasarkan uraian atau kondisi diatas bahwa masih diperlukan beberapa upaya pemberdayaan konsumen dimana dalam pemberdayaan konsumen selain oleh diri sendiri dan juga menjadi tanggung jawab produsen (pelaku usaha) dan negara atau pemerintah atau pihak ketiga. Oleh karena itu posisi konsumen yang lebih lemah itulah perlu Media

5 Abdul Halim Barakatullah. 2010. Hak-Hak Konsumen. Bandung: Nusa

${ }^{6}$ A.A Gd.Ag. Brahmasta, 2016, "Perlindungan Hukum Bagi Konsumen Dalam Perjanjian Baku Jual Beli Perumahan Denga pihak Pengembangan di bali”, Jurnal Kenotariatan Universitas Udayana, Acta Comitas, Volume 1 Nomor 2 , Oktober 2016.

7 Adrian Sutendi. 2008. Tanggung Jawab produk dalam Hukum perlindungan Konsumen. Bogor : Ghalia Indonesia. 
dicairkan formula dalam rangka lebih meningkatkan posisi tawar atau memberdayakan konsumen.

\subsection{RUMUSAN MASALAH}

Berdasarkan latar belakang permasalahan yang telah diuraikan, serta agar permasalahan yang akan diteliti menjadi lebih jelas dan penulisan penelitian hukum mencapai tujuan yang diinginkan, maka permasalahan pokok yang akan diteliti oleh penulis adalah :

1. Apakah yang menjadi faktor yang menyebabkan konsumen tidak berdaya ketika berhadapan dengan pelaku usaha yaitu BUMN dan Perusahaan Daerah ?

2. Bagaimanakah upaya pemberdayaan konsumen dalam menyelesaikan sangketa dengan pelaku usaha yaitu BUMN dan Perusahaan Daerah?

1.3 Tujuan dari penulisan ini adalah untuk mengetahui bagaimanakah pelaksanaan perlindungan hukum terhadap konsumen yang kurang mampu.

\section{ISI MAKALAH}

\subsection{METODE PENELITIAN}

Jenis Penelitian dalam jurnal ini dipakai jenis penelitian hukum yang bersifat empiris. Penelitian hukum empiris merupakan penelitian yang membahas bagaimana hukum beroperasi dalam masyarakat. Sedangkan menurut Peter Machmud Marzuki, penelitian hukum adalah suatu proses untuk menemukan aturan hukum, prinsip-prinsip hukum, maupun doktrin-doktrin hukum guna menjawab isu hukum yang dihadapi.Oleh karena itu, penelitian hukum merupakan suatu 
penelitian di dalam kerangka know-how di dalam hukum. ${ }^{8}$ Pendekatan yang digunakan dalam penelitian ini adalah pendekatan perundangundangan (the statute approach) yang dilakukan dengan cara mengkaji Undang-Undang, serta pendekatan konsep (conceptual approach). Adapun bahan hukum yang digunakan terdiri dari bahan hukum primer, bahan hukum sekunder, dan bahan hukum tersier, yang dianalisa secara kualitatif.

\subsection{PEMBAHASAN}

\subsubsection{Faktor Yang Menyebabkan Konsumen Tidak Mendapatkan suatu perlindungan ketika Berhadapan Dengan Pelaku Usaha Yaitu BUMN dan Perusahaan Daerah}

Ketidak berdayaan konsumen dapat dikategorikan sebagai berikut:

a. Ketika berhadapan dengan pelaku usaha Badan Usaha Milik Negara ( BUMN) dan Perusahaan Daerah:

1. Pelaku usaha BUMN dan Perusahaan Daerah dapat berkelit untuk memberikan ganti rugi apabila terjadi kerugian yang menimpa konsumen dengan alasan bahwa peraturan yang ada dan dibuatnya tidak mengaturnya. Peraturan yang ada tidak memuat tentang besarnya ganti kerugian olehkarenanya pada saat pembuatannya memang tidak dipersiapkan untuk

${ }^{8}$ Ari Maharta, 2018, “Pengalihwujudan karya sinematografi Menjadi Video Parodi Dengan Tujuan Komersial Perspektif Perlindungan Hak Cipta” Jurnal Universitas Udayana, Kertha Patrika, Volume 40 Nomor 1, April 2018. 
itu, sehingga dalil-dalil konsumen untuk menuntut ganti kerugian tidak kuat. Lagi pula pelaku usaha dengan posisinya yang kuat akan berusaha mengulurulur waktu dan balik mem-pressure konsumen.

2. Tidak berlangsungnya penyelesaian sengketa dengan jalur mediasi, pelaku usaha biasanya hanya diwakilkan oleh staff yang bertindak untuk dan atas nama perusahaan. Namun demikian, ketika penyelesaian sengketa telah mendekati final dan konsumen menuntut ganti rugi, wakil tersebut tidak berani memutuskan secara langsung. Biasanya ia minta waktu lagi untuk dengan alasan tuntutan konsumen sebesar ini akan dikonsultasikan dengan atasan terlebih dahulu. Inilah yang menyebabkan mundurnya waktu penyelesaian sengketa dari waktu yang sudah ditentukan sebelumnya.

3. Pelaku usaha berusaha mengulur-ngulur waktu atau upaya penyelesaian semhgketa dan tuntutan ganti rugi dari konsumen dengan alasan ia akan membentuk tim pengkaji ganti rugi terlebih dahulu. Inilah upaya pelaku usaha yang kelihatan agak licik dan kurang dapat diterima.

4. BUMN dan Perusahaan Daerah biasanya hanya sanggup memperbaiki, menyambung, menghidupkan lagi dan sejenisnya tanpa mau mengganti kerugian dalam bentuk materiil sesuai dengan isi perjanjian. Ini sebenarnya merupakan alasan klasik yang mungkin sudah di antisipasi, oleh karena itu perjanjian tersebut sengaja dibuat untuk menghindarkan diri dari 
kemungkinan mengganti kerugian pelanggan (Konsumen).

Beberapa pelaku usaha ini seolah olah menunjukan bahwa konsumen bersikap pasrah, apatis, dan tidak berdaya. Jalan keluar terbaik adalah bagaimana mengupayakan konsumen itu dapat lebih diberdayakan dalam menghadapi pelaku usaha.

b. Ketika Berhadapan dengan Pelaku Usaha Swasta:

Kadang kala konsumen yang dibuat menjadi tidak berdaya oleh pelaku usaha swasta. Berikut diajukan upayaupaya penyelesaian sengketa antara konsumen dengan pelaku usaha yang dilakukan oleh kalangan swasta, dengan beberapa pertimbangan yakni:

1. Pelaku usaha swasta biasanya hanya mau mengganti kerugian sekecil mungkin walaupun ia sebenarnya senang juga untuk menyelesaikan masalahnya dengan konsumen secara kekeluargaan. Maksud dari kekeluargaan disini adalah bahwa pelaku usaha tidak menutup kemungkinan menyelesaikan suatu sengketa dengan konsumen lewat perantara mediator melalui proses mediasi.

2. Pelaku usaha swasta biasanya juga beralih bahwa aturan-aturan yang telah ada itulah yang dipatuhi, padahal jelas-jelas bahwa peraturan tersebut sangat menguntungkan pelaku usaha dan pihak lain sangat memberatkan konsumen. Kondisi ini terjadi karena pelaku usahalah yang membuat dan menentukan isi perjanjian yang kemudian diajukan kepada konsumen. Oleh karenanya ia sangat 
berkepentingan dan mencari keuntungan sebanyak mungkin.

\subsubsection{Upaya pemberdayaan konsumen dalam menyelesaikan sangketa dengan pelaku usaha yaitu BUMN dan Perusahaan Daerah}

Pemerdayaan Konsumen dalam Penyelesaiian Sengketa

Upaya pemerdayaan terhadap konsumen dapat ditempuh lewat dua sisi yakni yang berasal dari dalam diri komsumen dan pemerdayaan konsumen karena intervensi dari pihak luar untuk meningkatkan daya tawar konsumen.

a. Upaya-upaya pemerdayaan dari diri konsumen. ${ }^{9}$

1. Perlunya peningkatan komunikasi hukum konsumen Harus didasari bahwa kebanyakan konsumen yang masuk terhadap masalah ini bukanlah dari kalangan akademisi, oleh karenanya mereka juga tidak begitu paham dengan masalah hukum. Dalam kerangka inilah konsumen harus lebih membekali diri sendiri dengan bertanya kepada yang lebih paham hukum, sering mendengarkan penyuluhan hukum baik lewat media maupun menghadiri dan mendengar secara langsung.

2. Peningkatan pemahaman hukum secara umum Hendaknya konsumen secara reguler memahami, membaca, mengupayakan, mengorek lebih dalam bagaimana cara agar ia lebih paham terhadap masalah yuridis.

3. Pemahaman Undang-Undang Perlindungan Konsumen

\footnotetext{
${ }^{9}$ Harry Hikmat. 2010. Strategi pemberdayaan Masyarakat. Bandung : Humaniora Utama Press
} 
Dengan berlakunya undang-undang perlinsungan konsumen, berarti secara luas seluruh masyarakat diharapkan dapat mengetahui akan hak dan kewajibannya sebagaimana telah ditetapkan dalam undang-undang. Upaya tersebut dapat tercapai jika masyarakat mau berusaha dan belajar sendiri.

Oleh karena itulah ketika berlangsungan upaya penyelesaian sengketa, hendaknya konsumen aktif dalam berperan serta ,membantu mediator dengan melakukan pressure terhadap pelaku usaha agar memenuhi tuntutan sebagai konsumen. Dalam rangka menciptakan masyarakat adil dan makmur maka perlu suatu pengkajian terus menerus baik dalam perangkat undang-undang maupun penegakan hukumnya yaitu seberapa jauh hukum dapat memberikan dan mengembangkan hak-hak individu dan kelompokkelompok yang tidak berdaya. 10 Artinya bahwa hukum itu harus mempunyai nilai yang praktis, nilai-nilai yang secara jelas tercermin dalam praktek penggunaan hukum dan pelaksanaannya. Karena konsep-konsep dan teori-teori yang baik sudah ada maupun mengembangkan yang baru terus menerus dalam membangun pengetahuan sosial yang memungkinkan kita dapat memahami dunia yang terus menerus berubah. Jadi disinilah kita dapat menarik suatu analisi bahwa peran mediator akan dapat meningkatkan posisi tawar konsumen agar seimbang dengan posisi tawar pelaku usaha.

Dalam pemerdayaan konsumen secara simultan harus dari dua arus yakni arus pertama dari bawah, kuat dan tersosialisai

\footnotetext{
${ }^{10}$ Husni Syawali \& Neni Sri Imaniyati (ed). 2000. Hukum perlindungan Konsumen. Bandung : Mandar Maju.
} 
secara baik dan merata di kalangan konsumen. Kedua dari arus atas, adanya lembaga/departemen dalam struktur kekuasaan yang secara khusus mengurusi masalah perlindungan konsumen.

\section{Penutup}

\subsection{Kesimpulan}

Dari analisi diatas dapat ditarik kesimpulan dalam garis besarnya yakni:

1. Faktor yang menyebabkan konsumen tidak berdaya ketika berhadapan dengan pelaku usaha yaitu ketika BUMN dan Perusahaan Daerah terdapat banyak alasan yang dapat dikemukakan yaitu posisi pelaku usaha yang demikian kuat menyebabkan sebuah aturan-aturan perjanjian dibuat oleh pelaku usaha secara sepihak, Pelaku usaha selalu berkelit untuk memberikan ganti rugi dengan alasan yang tidak diatur dalam peraturan, pelaku usaha selalumdiwakilkan oleh staffnya dan bukan pimpinanya,pelaku usaha akan membentuk tim pengkaji ganti rugi serta pelaku usaha hanya bisa memperbaiki dan tidak untuk menggantinya.

2. Upaya pemerdayaan dapat ditempuh melalui dua jalur yakni petama dari diri konsumen sendiri dilakukan dengan cara peningkatan komunikasi hukum konsumen, peningkatan pemahaman hukum secara umum, pemahaman terhadap undang-undang perlindungan konsumen . kedua pengaruh dari luar konsumen dengan cara penyuluhan hukum, acara dengar pendapat (talkshow), seminar tentang perlindungan konsumen. 


\subsection{Saran}

1. Sebaiknya konsumen membekali diri dengan berbagai macam pengetahuan yang berkaitan dengan perlindungan konsumen.

2. Sebaiknya hak dan kewajibannnya konsumen harus seimbang dengan hak dan kewajiban pelaku usaha,

\section{Daftar Pustaka}

\section{Buku-Buku}

Abdul Halim Barkatullah. 2010. Hak-hak Konsumen. Bandung : Nusa Media.

A.Sonny Keraf. 1998. Etika Bisnis Tuntutan dan relevansinya. Yogyakarta : Kanisius.

Bilson Simamora. 2001. remarketing for Business recovery. Jakarta: PT Gramedia Pustaka Utama

Ahmadi Miru. 2011. prinsip-prinsip perlindungan Hukum Bagi Konsumen di Indonesia.Jakarta : PT Radja Grafindo Persada

Adrian Sutendi. 2008. Tanggung jawab produk dalam hukum perlindungan konsumen. Bogor : Ghalia Indonesia 


\section{Jurnal Ilmiah}

Suraji, Pranoto, "PEMBERDAYAAN DAN PERLINDUNGAN HUKUM BAGI KONSUMEN DALAM RANGKA MELINDUNGI KEPENTINGAN KONSUMEN KURANG MAMPU' Jurnal Ilmiah, Fakultas Hukum Universitas Sebelas Maret Surakarta.

A.A Gd.Ag. Brahmasta, 2016, "Perlindungan Hukum Bagi Konsumen Dalam Perjanjian Baku Jual Beli Perumahan Denga pihak Pengembangan di bali" , Jurnal Kenotariatan Universitas Udayana, Acta Comitas, Volume 1 Nomor 2 , Oktober 2016.

Ari Maharta, 2018, "Pengalihwujudan karya sinematografi Menjadi Video Parodi Dengan Tujuan Komersial Perspektif Perlindungan Hak Cipta" Jurnal Universitas Udayana, Kertha Patrika, Volume 40 Nomor 1, April 2018

\section{Peraturan Perundang-Undangan}

Undang-Undang Nomor 8 Tahun 1999 Tentang Perlindungan Konsumen 